\title{
HLA-A24 and survivin: possibilities in therapeutic vaccination
} against cancer Mads Hald Andersen*1, Rikke B Soerensen ${ }^{1}$, Jürgen C Becker ${ }^{2}$ and Per thor Straten ${ }^{1}$

\author{
Address: ${ }^{1}$ Center for Cancer Immunotherapy (CCIT), Department of Hematology, Herlev University Hospital, Dk-2730 Herlev, Denmark and \\ 2Department of Dermatology, University of Würzburg, D-97080 Würzburg, Germany \\ Email: Mads Hald Andersen* - mha@cancer.dk; Rikke B Soerensen - rbs@cancer.dk; Jürgen C Becker - Becker_JC@klinik.uni-wuerzburg.de; \\ Per thor Straten - ps@cancer.dk \\ * Corresponding author
}

Published: 04 September 2006

Journal of Translational Medicine 2006, 4:38 doi:10.1 186/1479-5876-4-38

Received: 13 June 2006

Accepted: 04 September 2006

This article is available from: http://www.translational-medicine.com/content/4/I/38

(C) 2006 Andersen et al; licensee BioMed Central Ltd.

This is an Open Access article distributed under the terms of the Creative Commons Attribution License (http://creativecommons.org/licenses/by/2.0),

which permits unrestricted use, distribution, and reproduction in any medium, provided the original work is properly cited.

\section{Background}

The group of Sato recently attempted to identify a HLAA24-restricted epitope derived from the universal tumor antigen survivin. Although unsuccessful, they reported that an HLA-A24 restricted peptide (AYACNTSTL) derived from the survivin splice variant survivin-2B can be recognized by CD8(+) cytotoxic T-cells [1,2]. Subsequently, as described in this journal this survivin-2B epitope is the target in a phase I clinical study assessing the efficacy of survivin-2B peptide vaccination in patients with advanced or recurrent colorectal cancer expressing survivin [3].
As HLA-A24 is a very frequent allele expressed especially in the Asian population a survivin-derived HLA-A24 restricted epitope would be highly interesting in peptide based immunotherapy against cancer. Survivin is an apoptotic inhibitor that is expressed at high levels in a variety of malignancies. At present, four splicing variants are known for survivin (Survivin, Survivin-2B, SurvivindeltaEx3, Survivin-3B, and survivin-2 $\alpha$ ) [4-6]. Survivin is over-expressed in almost all cancers including lung, colon, breast, pancreas, stomach, liver, ovaries, and prostate cancer, as well as melanoma, and hematopoetic malignancies [7-9]. Data from a large analysis of human transcripts revealed survivin as the fourth most highly 
expressed protein in human cancer tissue compared to normal tissue [10]. In contrast, the expression and function in human cancer of the splice variant the survivin-2B is more indistinct. Thus, most studies describe survivin 2$\mathrm{B}$ as to be pro-apoptotic, and only to be expressed at low levels in most malignant tissues [11]. Furthermore, survivin-2B expression are significantly decreased in later tumor stages and inversely correlated with tumor differentiation and invasion [4,11]. Likewise, Islam et al (2000) reported that the expression of survivin-2B is predominant in some neuroblastoma with a good prognosis [12], indicating a possible unfavourable role of survivin-2B in cancer development [13]. In contrast, two recent papers show that high expression of survivin-2B variant is correlated with poor prognosis in cancer patients $[14,15]$. However, as survivin-2B is not expressed in many malignancies, survivin is a more attractive candidate as a general vaccination candidate than the splice variant survivin2B. In the present manuscript, we identified an HLA-A24 restricted epitope derived from the universal tumor antigen survivin.

\section{Materials and methods \\ Patients}

Peripheral blood lymphocytes (PBL) from HLA-A24 positive cancer patients were obtained from the University Hospital in Herlev, Denmark. The PBL were isolated using Lymphoprep separation and cryopreserved in FCS with $10 \%$ DMSO. Tissue typing was conducted at the Department of Clinical Immunology, The State Hospital, Copenhagen, Denmark. Informed consent was obtained from the patients before any of theses measures.

\section{Interferon- $\gamma$ and perforin ELISPOT}

The interferon- $\gamma$ and Perforin ELISPOT assays was used to quantify peptide epitope-specific interferon- $\gamma$ and perforin releasing effector cells, respectively as described previously $[16,17]$. Briefly, nitrocellulosebottomed 96-well plates (MultiScreen MAIP N45; Millipore) were coated with $7.5 \mu \mathrm{g} / \mathrm{ml}$ capture anti-human interferon- $\gamma$ (Pf-80/ 164, Mabtech, Sweden) or $30 \mu \mathrm{g} / \mathrm{ml}$ coating anti-human perforin (Pf-80/164, Mabtech) in $100 \mu \mathrm{l}$ sterile PBS per well. The wells were washed and T2-A24 cells (a kind from Yasuto Akiyama, Tokyo) and effector cells were added with or without $10 \mu \mathrm{M}$ peptide. In some assays isolated, CD8 positive T-cells were used as effector cells using CD8+ MACS microbeads (Miltenyi Biotec GmbH, Gladbach, Germany). After incubation $\left(37^{\circ} \mathrm{C} / 5 \% \mathrm{CO}_{2}\right)$ medium was discarded and the wells were washed prior to addition of the secondary detection $\mathrm{Ab}$, anti-human biotinylated interferon- $\gamma$ (Mabtech) at $2 \mu \mathrm{g} / \mathrm{ml}$ in $75 \mu \mathrm{l} \mathrm{PSB} /$ BSA per well or anti-human biotinylated perforin (Pf-344biotin, Mabtech) at $1 \mu \mathrm{g} / \mathrm{ml}$ in $100 \mu \mathrm{l}$ PSB, respectively. The plates were incubated at RT for $2 \mathrm{~h}$, washed, and 100 $\mu \mathrm{l}$ of streptavidin-ALP (Mabtech) diluted 1:1000 in PBS, was added to each well and the plates were incubated for one hour at RT and the enzyme substrate NBT/BCIP (Invitrogen Life Technologies) was added to each well. Upon appearance of dark spots, the reaction was terminated by washing with tap water. The spots were counted using the ImmunoSpot Series 2.0 Analyzer (CTL Analyzers).

\section{Results and discussion}

Recently, a library of overlapping nonamers spanning the length of the survivin protein was used to screen for peptides capable of binding to different HLA alleles, including HLA-A*2402 revealing that the peptides Sur20-28 (STFKNWPFL), Sur96-104 (LTLGEFLKL), Sur133-141 (RAIEQLAAM), Sur126-135 (ETAKKVRRAI) bind to HLA-A24 [18]. These peptides were not included in the study from Sato and colleagues. Subsequently, we scrutinized PBL from HLA-A24+ cancer patients of different origin by means of ELISPOT against these peptides as described [19]. Indeed, strong and frequent CTL responses were detected against Sur20-28 (STFKNWPFL) in cancer patients of different origin as exemplified in figure $1 \mathrm{a}$; an HLA-A24+ renal cancer patient and an HLA-A24+ breast cancer patient hosting strong spontaneous responses against Sur20-28. We were able to detect a response against Sur20-28 in three out of five examined cancer patients (figure 1). The IFN- $\gamma$ ELISPOT assay is one of the most useful techniques for immunological monitoring of

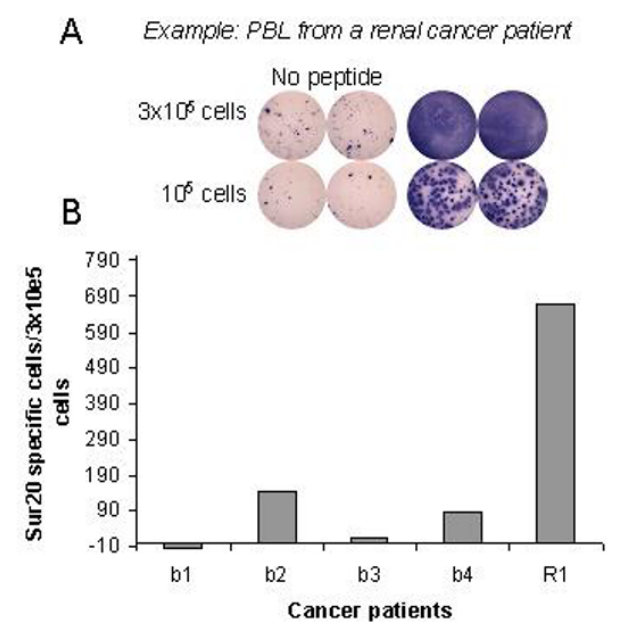

\section{Figure I}

HLA-A24 restricted T-cell responses against Sur2028 in cancer patients. A: Example of the ELISPOT plate performed with the strong responding renal cancer patient RI. B: Spontaneous T cell responses against Sur20-28 as measured by the ELISPOT assay. The average number of peptide specific IFN $\gamma$ spots formed in response to Sur20-28 among $3 \times 10^{5}$ in vitro stimulated PBL from four breast cancer patients (bI, b2, b3, b4), and I renal cancer patient (RI). Non-specific IFN $\gamma$ spots are subtracted. 
CTL responses and has gained increased application as a measure of specific T cell activation. Previously, we and others have identified CTL epitopes from e.g. survivin, Bcl-2, tyrosinase, CEA, EpCam and Mage on the basis of spontaneous T-cell responses in PBL from cancer patients as presented here [19-25]. However, the IFN- $\gamma$ ELISPOT does not assess cell-mediated cytotoxicity directly as IFN$\gamma$ secretion is not limited to only cytolytic CD8 T-cells cells. Thus, although it has been shown that IFN- $\gamma$ ELISPOT reactivity in most cases correlates with the capacity to exhibit cytotoxic function, the formal prove for this notion can only be obtained directly. Perforin is a key mediator of target cell death and the perforin ELISPOT assay was recently demonstrated to provide an estimation of cytotoxic effector cell frequency [17]. To insure that the ELISPOT positive cells were indeed CD8+ T-cells, we first isolated CD8+ cells from PBL from eight cancer patients. Subsequently, we analyzed these CD8+ cells both by IFN$\gamma$ and perforin ELISPOT (figure 2). In six out of eight patients we were able to detect not only an INF- $\gamma$ response but in addition a perforin response. Furthermore, the CD8 isolated cells from the eight patients were tested against the irrelevant, HLA-A24-restricted epitope from HIV-1 gag gp41 $1_{67-75}$ (RYLKDQQLL) [26]. Data from these experiments showed highly comparable results when testing unpulsed T2-A24 cells vs. T2-A24 cells pulsed with HIV-1 gag gp $41_{67-75}$, even after a 10 day stimulation of the CD8+ cells with the HIV-1 gag gp41 $1_{67-75}$ peptide (data not shown).

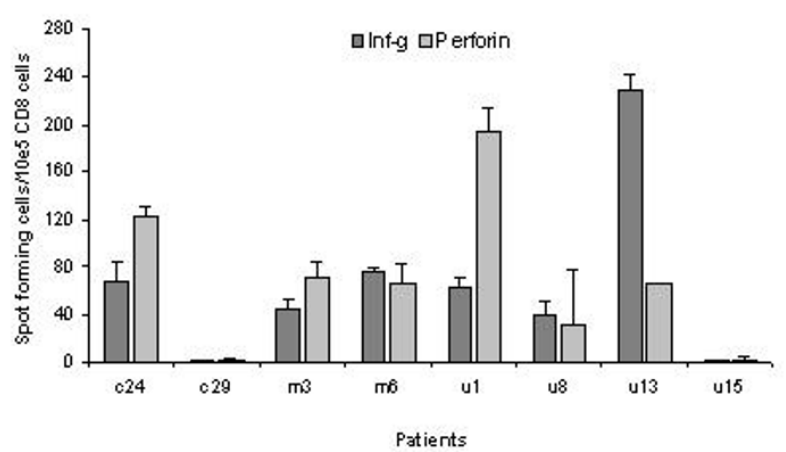

\section{Figure 2}

Detection of HLA-A24 restricted, sur20-28 specific, CD8 postitive cells by interferon- $\gamma$ and perforin. ELISPOT. CD8+ cells were isolated from PBL from two HLAA24+ breast cancer patients (c24, c29), two HLA-A24+ melanoma patients ( $\mathrm{m} 3, \mathrm{~m} 6)$, and four HLA-A24+ renal cancer patients (ul, u8, u I 3, u I 5). Spontaneous T-cell responses against Sur20-28 was measured by both interferon- $\gamma$ and perforin ELISPOT for all patients. The average number of peptide specific IFN $\gamma$ or perforin spots formed in response to Sur20-28 among $10^{5}$ in vitro stimulated CD8+ cells. Nonspecific spots are subtracted.
Thus, the Sur20-28 reacting cells in the patients PBL are indeed cytotoxic, CD8+ effector cells. Consequently, Sur20-28 is a very attractive target to be included in the ongoing survivin-based peptide immunotherapy against cancer.

\section{References}

I. Hirohashi Y, Torigoe T, Maeda A, Nabeta Y, Kamiguchi K, Sato T, Yoda J, lkeda H, Hirata K, Yamanaka N, Sato N: An HLA-A24restricted Cytotoxic $\mathbf{T}$ Lymphocyte Epitope of a Tumorassociated Protein, Survivin. Clin Cancer Res 2002, 8: I73।-1739.

2. Idenoue $S$, Hirohashi $Y$, Torigoe $T$, Sato $Y$, Tamura $Y$, Hariu H, Yamamoto M, Kurotaki T, Tsuruma T, Asanuma H, Kanaseki T, Ikeda H, Kashiwagi K, Okazaki M, Sasaki K, Sato T, Ohmura T, Hata F, Yamaguchi K, Hirata K, Sato N: A potent immunogenic general cancer vaccine that targets survivin, an inhibitor of apoptosis proteins. Clin Cancer Res 2005, I I: | 474-| 482.

3. Tsuruma T, Hata F, Torigoe T, Furuhata T, Idenoue S, Kurotaki T, Yamamoto M, Yagihashi A, Ohmura T, Yamaguchi K, Katsuramaki T, Yasoshima T, Sasaki K, Mizushima Y, Minamida H, Kimura H, Akiyama M, Hirohashi Y, Asanuma H, Tamura Y, Shimozawa K, Sato N, Hirata $\mathrm{K}$ : Phase I clinical study of anti-apoptosis protein, survivinderived peptide vaccine therapy for patients with advanced or recurrent colorectal cancer. J Transl Med 2004, 2: 19.

4. Mahotka C, Wenzel M, Springer E, Gabbert HE, Gerharz CD: Survivin-deltaEx3 and survivin-2B: two novel splice variants of the apoptosis inhibitor survivin with different antiapoptotic properties. Cancer Res 1999, 59:6097-6102.

5. Badran A, Yoshida A, Ishikawa K, Goi T, Yamaguchi A, Ueda T, Inuzuka M: Identification of a novel splice variant of the human anti-apoptopsis gene survivin. Biochem Biophys Res Commun 2004, 3 | 4:902-907.

6. Caldas H, Honsey LE, Altura RA: Survivin 2alpha: a novel Survivin splice variant expressed in human malignancies. Mol Cancer 2005, 4: II.

7. Ambrosini G, Adida C, Sirugo G, Altieri DC: Induction of apoptosis and inhibition of cell proliferation by survivin gene targeting. J Biol Chem 1998, 273: I I I77-I I I82.

8. Adida C, Haioun C, Gaulard P, Lepage E, Morel P, Briere J, Dombret H, Reyes F, Diebold J, Gisselbrecht C, Salles G, Altieri DC, Molina T]: Prognostic significance of survivin expression in diffuse large B-cell lymphomas. Blood 2000, 96: 1921-1925.

9. Grossman D, McNiff JM, Li F, Altieri DC: Expression and targeting of the apoptosis inhibitor, survivin, in human melanoma. $J$ Invest Dermatol 1999, I I3:1076-108I.

10. Velculescu VE, Madden SL, Zhang L, Lash AE, Yu J, Rago C, Lal A Wang CJ, Beaudry GA, Ciriello KM, Cook BP, Dufault MR, Ferguson AT, Gao Y, He TC, Hermeking H, Hiraldo SK, Hwang PM, Lopez MA, Luderer HF, Mathews B, Petroziello JM, Polyak K, Zawel L, Kinzler $\mathrm{KW}, .:$ Analysis of human transcriptomes. Nat Genet 1999, 23:387-388

II. Li F: Role of survivin and its splice variants in tumorigenesis. BrJ Cancer 2005, 92:2। 2-216.

12. Islam A, Kageyama H, Takada N, Kawamoto T, Takayasu H, Isogai E, Ohira M, Hashizume K, Kobayashi H, Kaneko Y, Nakagawara A: High expression of Survivin, mapped to $17 \mathrm{q} 25$, is significantly associated with poor prognostic factors and promotes cell survival in human neuroblastoma. Oncogene 2000, 19:617-623.

13. Meng H, Lu C, Mabuchi H, Tanigawa N: Prognostic significance and different properties of survivin splicing variants in gastric cancer. Cancer Lett 2004, 2 16:147- 155.

14. Taubert H, Kappler M, Bache M, Bartel F, Kohler T, Lautenschlager C, Blumke K, Wurl P, Schmidt H, Meye A, Hauptmann S: Elevated expression of survivin-splice variants predicts a poor outcome for soft-tissue sarcomas patients. Oncogene 2005, 24:5258-5261.

15. Wagner M, Schmelz K, Wuchter C, Ludwig WD, Dorken B, Tamm I: In vivo expression of survivin and its splice variant survivin2B: impact on clinical outcome in acute myeloid leukemia. Int J Cancer 2006, I 1 9:1291-1297.

16. Andersen MH, Pedersen LO, Capeller B, Brocker EB, Becker JC, thor Straten P: Spontaneous cytotoxic T-cell responses against survivin-derived MHC class I-restricted T-cell epitopes in situ as 
well as ex vivo in cancer patients. Cancer Res 200I, 61:5964-5968.

17. Zuber B, Levitsky V, Jonsson G, Paulie S, Samarina A, Grundstrom S, Metkar S, Norell H, Callender GG, Froelich C, Ahlborg N: Detection of human perforin by ELISpot and ELISA: ex vivo identification of virus-specific cells. J Immunol Methods 2005, 302:13-25.

18. Bachinsky MM, Guillen DE, Patel SR, Singleton J, Chen C, Soltis DA, Tussey LG: Mapping and binding analysis of peptides derived from the tumor-associated antigen survivin for eight HLA alleles. Cancer Immun 2005, 5:6::6.

19. Andersen $\mathrm{MH}$, Pedersen LO, Becker JC, thor Straten P: Identification of a Cytotoxic T Lymphocyte Response to the Apoptose Inhibitor Protein Survivin in Cancer Patients. Cancer Res 200I, 61:869-872.

20. Andersen MH, Reker S, Becker JC, thor Straten P: The melanoma inhibitor of apoptosis protein: a target for spontaneous cytotoxic T cell responses. J Invest Dermatol 2004, 1 22:392-399.

21. Andersen MH, Svane IM, Kvistborg P, Nielsen OJ, Balslev E, Reker S, Becker JC, Thor SP: Immunogenicity of Bcl-2 in cancer patients. Blood 2005, I5:728-734.

22. Scheibenbogen $C$, Sun $Y$, Keilholz U, Song M, Stevanovic S, Asemissen AM, Nagorsen D, Thiel E, Rammensee HG, Schadendorf D: Identification of known and novel immunogenic T-cell epitopes from tumor antigens recognized by peripheral blood $\mathrm{T}$ cells from patients responding to IL-2-based treatment. Int J Cancer 2002, 20;98:409-4I4.

23. Herr W, Schneider J, Lohse AW, Meyer zum Buschenfelde $\mathrm{KH}$, Wolfel T: Detection and quantification of blood-derived CD8+ T lymphocytes secreting tumor necrosis factor alpha in response to HLA-A2.I-binding melanoma and viral peptide antigens. J Immunol Methods I996, I9 I:I3I-I42.

24. Nagorsen D, Keilholz U, Rivoltini L, Schmittel A, Letsch A, Asemissen AM, Berger G, Buhr HJ, Thiel E, Scheibenbogen C: Natural T-cell response against MHC class I epitopes of epithelial cell adhesion molecule, her-2/neu, and carcinoembryonic antigen in patients with colorectal cancer. Cancer Res 2000, 60:4850-4854.

25. Valmori D, Dutoit V, Rubio-Godoy V, Chambaz C, Lienard D, Guillaume P, Romero P, Cerottini JC, Rimoldi D: Frequent cytolytic Tcell responses to peptide MAGE-AI 0(254-262) in melanoma. Cancer Res 2001, 61:509-5I2.

26. Ikeda-Moore $\mathrm{Y}$, Tomiyama H, Miwa K, Oka S, Iwamoto A, Kaneko Y, Takiguchi M: Identification and characterization of multiple HLA-A24-restricted HIV-I CTL epitopes: strong epitopes are derived from $\mathbf{V}$ regions of HIV-I. J Immunol 1997, 1 59:6242-6252.

\section{Publish with Bio Med Central and every scientist can read your work free of charge}

"BioMed Central will be the most significant development for disseminating the results of biomedical research in our lifetime. "

Sir Paul Nurse, Cancer Research UK

Your research papers will be:

- available free of charge to the entire biomedical community

- peer reviewed and published immediately upon acceptance

- cited in PubMed and archived on PubMed Central

- yours - you keep the copyright
BioMedcentral 